\title{
NEW HOMO ECONOMICUS: CONTEMPORARY CONTEXT
}

\section{Petinova O. B.}

\section{INTRODUCTION}

The Ukrainian scientific multidisciplinary discourse reflects the global valid trends in the study of the economic person. The thematic spectrum of research, which is in one way or another related to the development, application, references to models of economic person or its individual components is very diverse. Socio-philosophical research is intended to be the methodological basis of specific scientific research. This is fully supported by the existence of profound works by Ukrainian scientists dedicated to the study of economic (or related to this field) objects.

Analyzing the main social trends in the organization of socioeconomic relations, we came to the conclusion that it is necessary to comprehend the existing reality in the framework of complex sociophilosophical interdisciplinary research and to determine the guidelines for building the future of our state, the basis of which should be a new economic person managing the society of the social market economy.

With the transformation in all spheres of human being and changes in the social order, the patterns of human behavior, which were generally familiar to society, change. The gap appears between the image of a traditional type of man and society needs in the "new type" of man, which we call the new economic man. The traditional social type also exists (mostly these are older people), but new emerging economic conditions in which, unfortunately, the former personality traits that were targeted by the entire education and upbringing system in the country become irrelevant, hindered, and become an obstacle in the process of self-actualization and self-determination in life. Indeed, people want to act in accordance with the composition of their character, but their behavior either interferes with the achievement of economic goals, or the person is completely unable to act contrary to their beliefs. For example, such positive personality traits as credulity, openness to people, moderation under the market society conditions lose their value, and the aggressiveness, risk-taking ability, initiative, etc. become the priority. If in the Soviet society entrepreneurial people were called "speculators", nowadays it is considered prestigious 
and corresponds to the challenges of the time. Character traits that at one point helped to adapt to social conditions of the day do not meet the needs of the economy today, and economic development happens faster than character formation and the response of educational institutions and education to such changes; the gap between economic evolution, and psychological and behavioral evolution leads to the situation where in the course of ordinary economic activity the needs of both the individual and the society are no longer satisfied.

\section{The new Homo economicus: definition of the concept}

The French philosopher G. Bachelard said that the creator and the bearer of the future civilized society should be a person capable of overcoming ethnic and social isolation, and therefore able to live in the rhythm of millennia. Modern Ukrainian researchers state that the metaphysical dimensions of human being are aimed at comprehending the downturn of human existence, the problems of personality and consciousness destruction, the need to reconstruct their essence in accordance with the ideals of truth, goodness, beauty; self-understanding of ways individuals choose themselves as a subject of moral, aesthetic and spiritual action, focus on the higher "meta-existing" values of life is a process of self-realization, self-improvement, self-creation, which creates a bridge from the processes of material self-affirmation in a crisis society existence to spiritual higher existential states. The latter make a human human and contribute to positive self-determination, authentic selfrealization and self-creation, a process on which depend both the fate of a "lost society" and the fate of a "lost person", who must return their lost essence to become themselves as the highest value, mobilizing all mechanisms of holistic understanding of themselves and the world in their totality ${ }^{1}$. They go on to say that such methodological requirements for the anthropological model of Homo economicus as instrumental status, symbolism, constructiveness and idealization make it possible to draw the "most important methodological distinction" - to distinguish two concepts of Homo economicus: if the former considers Homo

${ }^{1}$ Соснін О. В., Воронкова В. Г., Постол О. С. Сучасні міжнародні системи та глобальний розвиток (соціально-політичні, соціально-економічні, соціальноантропологічні виміри). URL: http://pidruchniki.com/74058/politologiya/suchasni_ mizhnarodni_sistemi_ta_globalniy_rozvitok 
economicus as a purely theoretical model, sum of anthropological prerequisites and assumptions, in the second case we talk about the type of personality, with appropriate behavior, abilities, inclinations and value preferences. Therefore, we can conclude that Homo economicus in the second meaning is a "psychologized", subjective version of the ascending model, which relates to it as a conceptual notion of empirical realization, and they correlate with each other as a general and isolated, which determines the differences between logical and ontological status.

The notion "economic person of a new type" or in other words, we use the concept of "new economic person", fits quite well to indicate the image of the future man, which will become the basis of Ukrainian society and will meet the challenges of time. If as a basis we take the new model of economic person proposed by M. Storchev as a theoretical model, then the concept "new economic person" under the context of our study will refer to the "psychologized version," (market type personality). Thus, by "new economic person" we mean a socially oriented market person, characterized by a high level of economic culture, oriented towards the achievement of well-being, a high quality of life, social justice and security, has creative abilities, is capable of risk and rapid adaptation under the changing market conditions. Surely, rational thinking serves as its attribute. The new economic person, at the same time, is the social role that the individual has to play in society, because modern Ukrainian economic system requires major transformation, and the Ukrainian economy experiences this necessity to the full extent. Problems in the level of compensation, changes in demand for labor and strong competition reinforce the necessity to develop national entrepreneurship. The issue of competitiveness of a new economic person, which must be formed as an economic entity, is very relevant under the context of globalization processes in Ukraine.

The new Homo economicus must build Ukraine we can be proud of. We have ancient traditions and a rich cultural heritage, significant natural resources. The new economic person should not ask what the country can do for them, instead, they will seek the answer to another question: what they can do with the help of the state to fulfill their responsibilities, to protect their economic freedom and to realize their constructive intentions, and at the same time-for their country as a whole. Unfortunately, nowadays the creative initiative of citizens is often suppressed, and the state apparatus not only fails to help, but also 
impedes the achievement of new perspectives. History confirms that the main threat to freedom is the concentration of power, the state is required to preserve our freedom, and it is also an instrument through which we can benefit from our freedom; however, when power is concentrated in the hands of politicians, it becomes a threat to freedom, both economic and individual. In our opinion, functions of the state should be generally reduced to protecting the citizens (maintaining the law, order, etc.) and assisting in the exercise of economic freedom.

It is possible to distinguish objective and subjective factors of "psychologized" economic person formation. Objective ones include the environment, productive forces and industrial relations, socio-political life of society, national, family relations, etc. Subjective are the ideas of a person about themselves and their managerial activities when applied, in education, in upbringing, their feelings, thinking process, and understanding of their tasks. Often, researchers use the terms "condition" together with factors and generalize them. It should be noted that conditions become factors through activity and include those elements of objective and subjective conditions that have a decisive influence on personality formation. Thus, the terms "objective and subjective conditions" reflect the reality as it is, the elements of objective and subjective factors under different conditions are differently correlated; and subjective is nothing but an objective regularity, which is realized only as a subjective for each individual personality and is their worldview, feelings, passions, etc. The formation of individual and psychological features of the "psychologized" economic person, in our view, is determined both by the specific hereditary biological properties of the organism and by the social environment in which the individual lives and is raised. This is, in fact, the genetic and cultural level represented in the new model of M. Storchev's economic person.

The social mechanism of economy functioning and development cannot be considered without the social relations the new economic person enters, which brings its specific nature to any field, community or process in which the relations may be manifested. The worldview of the new economic person combines the unequal social positions of different social groups and classes, social organizations and institutions. Its economic behavior is realized through role-playing positions that include functioning at the theoretical and practical levels. Thus, through the comprehension of new knowledge and patterns of economic life through 
the social institute of education, the theoretical and cognitive function is realized, in predicting the probable prospects and tendencies of development of the socio-economic sphere and the economic future of the state the predictive one is realized; by providing the management system with highly qualified personnel accustomed to modern conditions and able to manage effectively - managerial; in the formation of market socio-economic outlook of all economic life participants, orientation to the modern view of the role of the new economic person in the construction of the future of Ukraine - ideological. In addition, the new economic person is a product of a market society, where the process of economic socialization is carried out in socio-economic relations, in which further they monitor socio-economic tensions in society by themselves.

The philosopher A. Herzen in his time noted that the dependence of man on the environment, on the age is beyond doubt, and this dependence is even stronger because half of the bonds are established behind the back of consciousness; there is a physiological connection here, one that can rarely be overcome by the will and the mind; there is an element of heredity that is brought with birth in the same way as face features, there is also an element of morality and physiology - education, which imparts history and modernity to the person, and finally, the element of consciousness ${ }^{2} \ldots$ So, the environment changes, personality changes, as well as its peculiarities. Accordingly, different historical ages in different social relations bring certain features, characteristic for their time, for their people, for their state, and the model of the economic person changes.

The process of formation and evolvement of a "psychologized" new economic person is a complex dialectical process that includes the conditions of life, upbringing, and education; it is, first of all, economic sphere, purposeful external influence of social communities, mass media, etc. In this case, the inner aspirations, beliefs, character, success are determined by how much the person wants to be themselves, how they want to meet the challenges of time, whether they are engaged in selfeducation and self-development. The individual and psychological features of an economic person are determined by social conditions. Thus, these processes are especially noticeable during the period of

${ }^{2}$ Герцен А. И. Избранные философские произведения. В 2 т. Т. 2. Москва, 1948. 368 c. C. 111. 
change of the country's economic system type, for example, in Ukraine the administrative command economy changed to a market one, which led to new, qualitatively different conditions of life, activity, management, respectively, and the economic person became qualitatively different. It is not the external conditions per se, but the economic activity of a person in these conditions, their active interaction with the environment that play a crucial role in the formation of individual characteristics of a new type personality, which we call the market type.

One cannot practically educate another person without "rewiring" their psychology, which, above all, is expressed through the mental properties of the individual. This problem is not only theoretical but also practical. Therefore, building our country, enhancing its competitiveness in the international market will depend not only on the implementation of modern IT technologies in the manufacturing process, but, above all, on the economic activity subject, who will work for themselves and for the benefit of the state. New principles of economic policy at the present stage include strengthening the role of economic methods and incentives in the country's economy organization, expanding the autonomy of regions, decentralization of power, maintaining the initiative of the regions, increasing the responsibility and material interest of employees in the results of their activities. Improving the forms of economy management, active participation of the working team in the development of plans for the future, taking into account non-standard creative approaches will give Ukraine the opportunity to take a prominent place among the highly developed countries of the world. Modern tasks of economic planning and stimulation require from each citizen the use of the mind, knowledge, initiative, intuition, display of one's best abilities; in their turn, new forms and methods of management must bring material, intellectual, moral satisfaction, an opportunity to reveal one's talents. Thus, the implementation of economic reforms is based on changes in the management psychology, and economic transformations depend on psychological transformations: it is necessary to replace the psychology of labor and management, with humanism remaining the main principle. The basic rule of organizing everyone's behavior should be creative search, scientific foresight, which requires the development of new traits in the character of each employee, the manifestation of their abilities and will.

The basis of economic reforms is a change in the psychology of the economic person. One of the main problems is the change in business 
ethics and, in fact, it is the most difficult one. The demoralization of the population, first of all, youth deviance, alcoholism, drug addiction, sexual misconduct are those diseases of the XXI century that are very difficult to combat. At the same time, for example, the nature of prostitution and the nature of money are analogous, in the context of goods/money material, alienated relationships prostitution becomes a symbol of interpersonal relationships. Prostitution was the oldest profession. It is unlikely, if the profession is understood as labor specialization in the times of the preclass society (hunter, cattleman, farmer), then we could supplement this list with it. It arises with the emergence of goods/money relations, and on their basis. From our point of view, there are no reasons for prostitution itself, there are, however, social reasons, contradictions of socio-economic development, which create various forms of deviant behavior.

Drunkenness is a very common social phenomenon. It reflects all the smallest nuances of the social environment, always restoring the lost positions and winning the new. Every time life confirms that it is impossible to eradicate drunkenness with good intentions only. Alcoholism occupies a dominant position among the youth subculture. The social impact and pressure of crime on society, the spread of certain moral norms, psychological contamination of the least unstable part of the population environment is a worrying reality of the present, which leads to a significant and stable deformation of value system. O. Khimchuk notes that such values as honor, dignity, modesty, charity, compassion, conscience, true love, justice, social training, good manners, religiosity, cultural values, politeness, and pride are not preferential for modern youth. Material values, as well as selfishness, cruelty, rudeness, are gaining importance ${ }^{3}$. Nowadays, such value as the responsibility of young people to their parents, and therefore to society, is lost as well. Equally important is the careless attitude of young people to the environment (vegetation, animals, water resources, etc.), which negatively affects the health, physical and mental development of the people. Based on the results of her research of the modern youth values system, S. Nezabitovskaya gives a leading place to material well-being. Family happiness is gaining more weight, but creative development and the aesthetics of life are losing their

3 Химчук О. Цінності сучасної молоді. URL: http://www.osvitata.com/osvita-tareligiya/tsinnosti-suchasno-molodi.html. 
relevance ${ }^{4}$. Now, the question is: how do we fight this? In our opinion, among the ways and means of fighting this problem in modern conditions, due attention should be paid to the social teachings of the church, because the general ethics of work lies in morality, and common prayer has always been a source of religious ethics, a high culture of professional partnership relations, professional morality, and lawabidingness.

\section{New ethics of management: philosophical aspect}

The question of the interrelation between ethics and economics is quite complex, but it is properly presented in socio-philosophical thought. Thus, ethics is the set of principles, rules, and norms of behavior adopted in a social environment or professional group (ethics of teachers, ethics of doctors, etc.). In addition, ethics is also understood as the doctrine of morality, which is a form of consciousness. Public morality is based on public opinion, human beliefs, traditions and habits. Morality and ethics are very closely linked; the moral qualities of an economic person are reflected in the actions, economic behavior in general, attitude towards people, family, work, and their responsibilities. The moral and ethics of the economic person are formed in the process of human experience accumulation, in certain historical conditions, and depends on the development of science, new technologies, and above all, on the renewal of economic life and the economic system as a whole. With changing economy comes changing behavior, changing relationships between people and their morals.

A. Sen, an American professor of Indian descent, widely known today as a thinker who directs economic theory to socio-ethical issues, was the 1998 Nobel Laureate in Economics "for his contributions to welfare economics". His book "On Ethics and Economics", is often called the treasure chest, it shows the organic connection between economic science and the philosophy of morality, and highlights the damage done to economic analysis by the preoccupation with economic behavior postulate. A. Sen distinguished ethics and engineering as two sources of modern economic theory. Disconnection the economy from

4 Незабитовська С. Цінності сучасного студентства. URL: http://nadoest.com/ cinnosti-suchasnogo-studentstva.

${ }^{5}$ Сен А. Об этике и экономике. Москва, 1996. 159 с. 
ethics is one of the important reasons of classical analysis insufficiency. The thinker divides the material economics and the welfare economics. Since ethical motives influence human behavior, they influence material processes acting as welfare factors. Modern economic thought can become more effective if it uses ethical factors, as they shape human judgment. However, to achieve it, it is first necessary to improve human proper ethical conceptions.

Thus, the main directions of economic theory identify the rationality of behavior with the internal independence of choice and maximization of self-interest. However, A. Sen doubts that the focus on the interest maximization is close to the true human behavior. In the Japanese economy, for example, there are systematic deviations toward a course of action based on concepts such as duty, loyalty, and good will. These circumstances helped to raise the level of individual and group economic efficiency. The thinker does not share A. Smith's conception, and at the same time writes about the possibility of such circumstances under which the pursuit of self-interest satisfaction can only be ethically justified, also tries to restructure the term "welfare": welfare should be distinguished in the context of personal virtues and achievements and in light of broader goals, such as distributive justice, coherence, and interdependence. A. Sen proclaims ethics and engineering to be the source of economic theory development. Ethical orientation is directed to the Aristotelian tradition, while the engineering approach is associated with the name of French economist and mathematician of the XIX century L. Walras. The problem lies in finding a balance between an ethically oriented and technically feasible approach. The distancing of modern economic theory from ethical theory impoverishes the fundamental science. In 1975, A. Sen delivered an essay "Smith Travels on the Ship of State," where he interprets the thinker's idea about human behavior of convenience, because the philosopher believes that personal selfish interest dominates in most people, and according to A. Sen, the concepts of "convenience" and "personal gain," should not be equated, because even A. Smith, explaining the term, understands it as a combination of thoughtfulness and self-control, which is not identical to selfishness, and that convenience is the most useful of the virtues of man as an individual ${ }^{6}$.

\footnotetext{
${ }^{6}$ Сен А. Об этике и экономике. Москва, 1996. 159 с.
} 
One of the directions for the development of ideas of philosophical and ethical school in economics is the theory of "quality of life," the essence of which V. Brandt associates with material well-being and growth of the economy as a whole, but says that where material desires are satisfied, the question about justice arises. What does prosperity mean if people are choking on smoke and debris? Therefore, the conclusion is that the economic growth should not be deified, such materialism is inhumane. The transition should be made from maximizing economic growth to optimization. The prosperity of the new quality requires a reorientation of economy, technology, and politics. There are a few determinants of the ethical problems emergence in professional activity and in general, in everyday life, such as insufficient level of moral consciousness development, lack of skills of ethical behavior and ethical relationships in business interaction ${ }^{7}$, and in our opinion, the most important problem of Ukrainian society is the clear uncertainty and inconsistency of ethical standards of behavior.

Traditionally, within the framework of ethics, such sections as axiology, aretology, feliology, deontology, thanatology, and the doctrine of justice are distinguished ${ }^{8}$. A core value in economics is utility, which can be expressed in value, profit or benefit. Among the virtues of an economic person we can distinguish thoughtfulness, ability to forethought, carefulness, all these qualities are a consequence of rationality and the desire for efficiency, the ability to generate a higher value in the course of their activities if compared to the value spent. Such virtue as the ability to fulfill given obligations intersects with deontology in ethics, and has a direct impact on contractual obligations, loans, interest on loans, and development of the capital market as a whole. The deontological aspect of economic activity is expressed in such terms as opportunism and information asymmetry. Happiness in economic science is associated with utility maximization, satisfaction of both material and intangible needs. Overall, the motivation for happiness can even be associated with the work process itself and with the economic life.

${ }^{7}$ Креденцер О. В. Інноваційність як важлива характеристика підприємницької поведінки менеджерів освітніх організацій. Актуальні проблеми розвитку організаційної та економічної психології в Україні. Тези I Всеукраӥнського конгресу з організачійної та економічної психології (29 червня - 2 липня 2011 року, м. Кам'янеиь-Подільський). Київ, Кам'янець-Подільський, 2011. С. 140-141.

${ }^{8}$ Разин А. В. Этика. Москва, 2006. 624 с. 
Thanatology is connected to understanding of time resources limitations, and is associated with organization life cycle, the problem of intertemporal choice, capital depreciation, choice between accumulation and cost, profit and risk, etc.

The study of justice is closely linked to ethics as a section of the economy (according to A. Sen), justice relates to the relations of distribution and redistribution, of property. This issue has recently been studied in the works of R. Malakhov, A. Hubar, V. Shabashev. In his work "On Economics and Ethics," A. Sen proposes to present the interrelation of ethics and economics with the use of theoretical and economic tools, that is to extend the economic imperialism methodology to the ethical sphere. In particular, an attempt to unravel the relationship between ethics and economics through a consumer choice model, a manufacture marginal productivity model, and a market pricing model is presented in R. Malakhov's article?.

The problem of a new economic person formation, in our opinion, has a close connection with the morally effective economic activity in the aspect of religion: from the internal to the external. The Compendium reads: "Real social change is effective and lasting as long as it is a manifestation of decisive change in personal behavior. True moral improvement of social life is not possible until it begins with a person and is oriented towards it: for "moral life attests to the dignity of the individual." The development of the moral qualities (justice, honesty, truthfulness, etc.) that are fundamental to a society that seeks to be truly "human" rests with man; it cannot be expected of others or entrusted to institutions. The task of every individual and in particular those who are endowed with various forms of political, legal or professional responsibility is to become a sensitive conscience of society and the first to attest to the civil coexistence worthy a person ${ }^{10}$."

V. Zhukovsky, the editor-in-chief of "Christian and the World," notes that until "...a person embarks on the path of inner change, purification, transformation, spiritual and moral maturity and integrity; does not dig into themselves in search of truth, goodness and beauty, all

9 Малахов Р. Г. Взаимосвязь этики и экономики: попытка формализации. Вестник Алтайской академии экономики и права. Барнаул, 2013. № 52. С. 15-18.

10 Компендіум соціальної доктрини Церкви. URL: http://www.vatican.va/ roman_curia/pontifical_councils/justpeace/documents/rc_pc_justpeace_doc_20060526_com pendio-dott-soc_uk. 
their external activity, no matter what good 'PR' or need it is covered with, will remain a servant of the sinful passions that motivate them... Effectiveness of work that is not blessed by God because it is based on sin has no solid foundation and will disappear during the first life trials. A professional in any industry, enslaved by sinful passions, becomes a source of further spread of spiritual illness, disharmony and moral degradation in society. Every personal sin is attributed to the total pathological degeneration of values in different strata of society, which eventually degenerate into 'structures of sin,' preventing any positive progression at all levels of society's life and activity. Alternatively, every healthy family or professional 'cell' of the social body has a positive effect on rehabilitation of everyone and everything that surrounds $\mathrm{it}^{11}$." V. Zhukovsky concludes with these thoughts, and one cannot disagree with him. The state of the anomic society of Ukraine has devastated and fouled Ukrainians to such a degree that it is only possible to restore trust in the state and build a new foundation of ethical relationships if they turn to their inner "self", to Christian spirituality as a source of human maturity and work efficiency, to manage their household, organize private business. It must be the basis for true management efficiency and entrepreneurial activity. In addition, the term "economy" from the Greek word oikonomia (oikos - household, dwelling, environment, nomos law), literally means the laws of housekeeping. The most important treatise on the economy of Ancient Greece is the "Oikonomia" of Xenophon. At the same time, the same concept of oikonomia is one of the most important ones in theology (as economy) and denotes divine providence for man and the entire created world, that means one term denotes the management of man and the management of God. Thus, only in combination the human management will be effective and successful. In the global business environment nowadays it is quite common to focus on such philosophical categories as "business ethics", "moral standards", "protection of human dignity and human rights", etc. Well-known brands and companies state that with the growth of spiritual values, both the profits of the companies and the general mood and ethical behavior increase proportionally, and the role of the leader in the enterprise involves making managerial decisions, resolving conflicts, realizing

11 Жуковський В. Журнал «Християнин і світ»: мета і завдання. Християнин $i$ світ. Львів, 2009. № 1. С. 3. 
oneself and at the same time taking into account the interests of people. The future is for the proactive and strong personalities who bear responsibility beyond the limits of their own "Self", the future is for the new economic person.

At the same time, one of the variants of the theory of value (the source of which is God) is neo-Thomism, which at the objective idealistic philosophical doctrinal level seeks to systemize faith and reason, religion and science into a coherent harmonious system. It is God who completes the neo-Thomistic hierarchy of values through the chain "individual common good - personality - religious values."

In our opinion, it is quite interesting to refer to the biblical understanding of the notion of wealth as a good in universal scope, beyond the country or nation in the study of an economic person who is concerned with gain, profit (as values), and a rational way of thinking. "Excerpts from the Dictionary of Biblical Theology" states: "By blessing the work of human hands, God completes and strengthens man $-\mathrm{He}$ creates them. But if a man forgets about God, then He destroys what is done without him ${ }^{12}$." Ukrainian researcher M. Homa ${ }^{13}$ in her works presents the detailed analysis of wealth and other economic categories in the Bible. Understanding the wealth (as a collection of material goods) as owning property, the amount of which far exceeds the vital needs of man, let us turn to the presentation of it in Holy Scripture. Thus, in the Old Testament wealth is presented as a blessing sent by God to a righteous man: "... Abraham was very rich in cattle, in silver and in gold ..." (Genesis 13: 2). The Lord enriches his chosen ones, but they must serve a particular higher purpose, no one is enriched for themselves only, wealth must serve thy neighbor. The subject of wealth is presented in the Book of Proverbs, the Book of Ecclesiastes, and the Wisdom of Sirach.

Let's look at some excerpts from these works as an example. "When a rich person stumbles, his friends will steady him, but if a poor person falls, his friends will have nothing to do with him. When someone rich makes a mistake, there are many people to cover up for him and explain away all the things he never should have said. But let someone poor make a mistake, and he gets nothing but criticism. Even if what he says makes

${ }^{12}$ Витяги із Словника Біблійного Богослов’я. Львів, 1996. С. 96-98.

13 Хома М. Біблійне розуміння багатства, або як християнам ставитися до матеріальних благ? Християнин і світ. Львів, 2009. № 1. С. 4-15. 
good sense, nobody will listen. When a rich person speaks, everyone is silent, and they praise him to the skies for what he says. But let a poor person speak, and everybody says, "Who is that?" They push him down if he so much as stumbles. There is nothing wrong with being rich if you haven't sinned to get that way. But there is nothing sinful about being poor, either. Only the ungodly think so."(Sir. 13, 22-24) “...I went past the field of a sluggard, past the vineyard of someone who has no sense; thorns had come up everywhere, the ground was covered with weeds, and the stone wall was in ruins. I applied my heart to what I observed and learned a lesson from what I saw: "A little sleep, a little slumber, a little folding of the hands to rest - and poverty will come on you like a thief and scarcity like an armed man.”(Proverbs 24, 30-34)

M. Homa's main illusions and dangers of wealth are abuse of power and office, arrogance and superstition, belief in the power of wealth and the rejection of God. Although the church is separate from the state, the moral and ethical issues raised by religion are immanently inherent in everyone's economic behavior, regardless of the position you hold president, MP, doctor, lawyer, teacher, businessman, janitor, cleaner, etc. - there must be certain moral and ethical standards that are the same for everyone, and everyone must adhere to them. Absolutely all human effort is futile without God. And if this is not the case then everyone will have "their own truth." And we have what we have. The New Testament Gospel of Matthew says: "...Do not store up for yourselves treasures on earth, where moths and vermin destroy, and where thieves break in and steal. But store up for yourselves treasures in heaven, where moths and vermin do not destroy, and where thieves do not break in and steal..." (Mt 6: 19-20)

M. Somin while researching the main paradigms of Christian attitudes to the economic and social sphere distinguished four of them: "miracle economy," "moderate doctrine," "patrimonial property doctrine," "protestant ethics." According to the first doctrine, the Lord gives everything by faith, including material necessity. In fact, a "miracle economy" means the renunciation of any arrangement of socio-economic sphere. According to the "moderate doctrine" (the conventional concept outlined in the patristic period at the end of the II at the beginning of the III century by Clement of Alexandria) to be rich is not evil, property gives the means of subsistence, is the guarantor of public freedoms and moral development of the person. However, independence of wealth must 
be a prerequisite for owning it: it is not wealth man that owns man, but man who owns wealth. "Great Church Fathers Doctrine" (teachings of the Holy Fathers of IV - V centuries: Basil the Great, Gregory the Dialogist, Ambrose, John Chrysostom) is presented on a personal level, "psychology of one's own" (property is considered the strongest temptation, and its overcoming in rejection of it) and at the level of relations with neighbors it is "sociology of property" (community of property). Communism derives from Christian love, but is only possible in a society where there is no private ownership (in fact, the utopias of T. More and T. Campanella are examples). "Protestant Ethic" (M. Weber) considers welfare and wealth as positive Christian values. The desire to increase wealth through legitimate capitalist mechanisms is a virtue. For the new economic person from the four presented doctrines, in our view, the most moderate is the "moderate doctrine" and "protestant ethic." Market economy conditions bring a competitive environment to the life and work organization of Ukrainians, but competition must be fair.

The modern younger generation of Ukraine is a product of capitalist society. A new economic person must believe in their ability to change the country for the better at the macro level, and believe in the success of their own role in the process at the micro level, in the success of their business. They must love money, otherwise there will be none, but the wealth must not possess them. And the possession of wealth does not hinder the salvation of the Christian only "if he will manage the wealth well, while remaining indifferent to it."

Discussing the topic of the socio-economic dimension of Christian life, L. Padovese states that the earthly gifts that man receives from God for proper use, the devil through his temptation tries to use them so that they become a source of wrongness for man, and overcoming the injustices from which society suffers depend on the internal transformation of man, and not on the mere change of structures ${ }^{14}$, and O. Kashchuk continues this thought: “... when unrighteous people have a wealth of earth, they only think how to use gifts of the earth received from God for the evil ${ }^{15}$."

14 Падовезе Л. Отці церкви IV-V століття про соціально-економічний вимір життя християн. Християнин і світ. Львів, 2009. № 1. С. 28-31.

15 Кащук О. Августин та папа Григорій Великий про праведне і неправедне володіння земними благами. Християнин і світ. Львів, 2009. № 1. С. 32-33. 
Today, the topic of spirituality and business is trending among the clergy, entrepreneurs and caring people from various fields of activity. The father-doctor Prokopiy Lototsky tries to answer the question of determining the system of values of the businessman. In the sermons, he speaks of four common mistakes distiguished by the Holy Scripture. The first is that people when making their plans forget God, so it is not surprising that true success bypasses them: “... it is sad to see those who consider themselves Christians, but act as if there is no God, as if his dwelling place is somewhere in the church, on the yellowed pages of the prayer book, in the old rites"; the second mistake is that we take tomorrow for granted, we act as if tomorrow will definitely come, but remember that life is unpredictable and short, "... what is the time? The moment we live in." The third mistake is that it is peculiar for people to put off the good for later, and the problem of evil is not only evil itself, "the hidden trap is the postponement of worthy work for tomorrow... but tomorrow may not come." And the last, the fourth one is wealth controls people, and not people control wealth, "true wealth is the ability to use what you have ${ }^{16}$."

The Church's social doctrine emphasizes that the economy has a moral dimension. As in the realm of ethics economic arguments and demands must be taken into account, so in the realm of economics one must be open to ethical requirements: "in the economic and social life one must respect and develop the dignity of man, his vocation and the good of the whole society. After all, man is the creator, the center and the goal of all economic and social life ${ }^{17}$."

Spirituality must be an integral part of the new economic person as its organic component of social nature. Spiritual wealth gives another impulse to its rational economic activity, maximizing utility in social development. An important component of the phenomenon of the new economic person, spirituality is a sense of responsibility to God, to themselves, their people and society as a whole, for their actions, everyone has the right to make mistakes, but one should not avoid the

16 Духовність і бізнес. Чи можливе поєднання? Зовнішньоекономічний кур'єр. Львів, 2016. Січень-лютий. С. 21. URL: http://lcci.com.ua/wp-content/uploads/ 2014/03/ZK-1-2016-web.pdf

17 Компендіум соціальної доктрини Церкви. URL: http://www.vatican.va/ roman_curia/pontifical_councils/justpeace/documents/rc_pc_justpeace_doc_20060526_com pendio-dott-soc_uk.pdf 
state of metanoia. As a phenomenon of human existence, repentance exists in a distinct system of moral relations well-established by society. Only the people, community, society have the right to a final sentence.

\section{CONCLUSIONS}

The new economic person should become the engine of economic development in Ukraine, acting as the driving force that builds the economic life of society as a whole. By uniting into groups, organizations and with relevant economic institutions, the new economic person becomes the subject of socio-economic processes and a component of socio-economic development. The absolute priority of self-interest as a motive for economic activity makes it possible to draw conclusions about the ethical side of an economic person behavior, and at the same time may speak about the deviation of their economic behavior from the socalled "standards," which may be motivated by sympathy for another, kindness, irrational unconscious urges. Becoming a new economic person in Ukraine requires a qualitatively different economic system that will become the "basis" for changes in the "superstructure."

\section{SUMMARY}

The article suggests the definition to the concept of "new economic person." The author distinguishes Homo economicus as a theoretical model and sum of anthropological prerequisites and assumptions, and Homo economicus as a type of personality with appropriate behavior, abilities and value preferences. The objective and subjective factors of the psychologized Homo economicus formation are considered.

The way to form a new economic person is to change the ethics of management. One aspect of this issue is the close connection with morally effective economic activity in the aspect of religion. The moral improvement of social life must begin with and be guided by the individual.

\section{REFERENCES}

1. Витяги із Словника Біблійного Богослов'я. Львів, 1996. C. $96-98$.

2. Герцен А. И. Избранные философские произведения. В 2 т. Т. 2. Москва, 1948. 368 с. 
3. Губарь А. И. Собственность в системе социальноэкономических отношений. Вестник Алтайской академии экономики и права. Барнаул, 2010. Вып. 1 (14). С. 7-12.

4. Духовність i бізнес. Чи можливе поєднання? Зовнішньоекономічний кур'єр. Львів, 2016. Січень-лютий. С. 21. URL: http://lcci.com.ua/wp-content/uploads/2014/03/ZK-1-2016-web.pdf.

5. Жуковський В. Журнал «Християнин і світ»: мета і завдання. Християнин і світ. Львів, 2009. № 1. С. 3.

6. Кащук О. Августин та папа Григорій Великий про праведне і неправедне володіння земними благами. Християнин і світ. Львів, 2009. № 1. С. 32-33.

7. Компендіум соціальної доктрини Церкви. URL: http://www.vatican.va/roman_curia/pontifical_councils/justpeace/docume nts/rc_pc_justpeace_doc_20060526_compendio-dott-soc_uk.pdf.

8. Креденцер О. В. Інноваційність як важлива характеристика підприємницької поведінки менеджерів освітніх організацій. Актуальні проблеми розвитку організаційної та економічної психологї̈ в Україні. Тези I Всеукраїнського конгресу з організачійної та економічної психології (29 червня - 2 липня 2011 року, м. Кам'янець-Подільський). Київ, Кам'янець-Подільський, 2011. C. $140-141$.

9. Малахов Р. Г. Взаимосвязь этики и экономики: попытка формализации. Вестник Алтайской академии экономики и права. Барнаул, 2013. № 52. С. 15-8.

10. Незабитовська C. Цінності сучасного студентства. URL: http://nadoest.com/cinnosti-suchasnogo-studentstva.

11. Падовезе Л. Отці церкви IV-V століття про соціальноекономічний вимір життя християн. Християнин $і$ світ. Львів, 2009. № 1. C. 28-31.

12. Разин А. В. Этика. Москва, 2006. 624 с.

13. Сен А. Об этике и экономике. Москва, 1996. 159 с.

14. Соснін О. В., Воронкова В. Г., Постол О. Є. Сучасні міжнародні системи та глобальний розвиток (соціально-політичні, соціально-економічні, соціально-антропологічні виміри). URL: http://pidruchniki.com/74058/politologiya/suchasni_mizhnarodni_sistemi _ta_globalniy_rozvitok. 
15. Химчук О. Цінності сучасної молоді. URL: http:// www.osvitata.com/osvita-ta-religiya/tsinnosti-suchasno-molodi.html.

16. Хома М. Біблійне розуміння багатства, або як християнам ставитися до матеріальних благ? Християнин і світ. Львів, 2009. № 1. С. 4-15.

Information about the author: Petinova O. B.

Doctor of Philosophy, Professor at the Department of Philosophy, Sociology and Management of Socio-Cultural Activity, State Institution «South Ukrainian National Pedagogical University named after K. D. Ushynsky» 26, Staroportofrankovskaya str., Odesa, 65000, Ukraine 